Reference

SAID, Edward w (1985) Orientalism

Harmondsworth: Penguin.

\section{Beyond the Pale: White Women, Racism and History}

Vron Ware

Verso: London 1992, ISBN 0860915522

$£ 11.95,263 p p$.

This is both an ambitious and a modest book: its theme is huge, while its approach is necessarily selective, and its conclusions for a future feminist antiracist politics are tentative and provisional. As Ware emphasizes, the book represents something of a path-clearing exercise, helpfully exposing blindspots of existing feminist history and politics, suggesting directions that future historical research could take. Ware's book is divided into five sections. The first discusses a range of contemporary British images of white womanhood, exploring the racialized basis and ideological function of white femininity. The next three sections discuss aspects of white women and their relations to racism within history. The first of these examines the activities of white British women abolitionists in the early nineteenth century, and moves on to consider the shifting ideological relations between nineteenth-century feminists and the institution of slavery. This is followed by a reflection on the relationship between feminism and imperialism during the (late nineteenth-century) Age of Empire. The fourth section centres on the 1890 s involvement of white British women in campaigns against the US practice of lynching, and the book's final section returns to contemporary Britain with a consideration of the historical implications of many feminists in colonialism and the ways in which a future antiracist feminism could develop.

The result is an important, if uneven, series of case studies. One of Ware's most valuable, if ambiguous, contributions is her argument for the political necessity of analyzing whiteness as an ethnicity; as she points out, 'white feminists have managed to avoid dissecting these cultural and racial components of white femininity, although they have become eager to hear what black women have to say about their racialized and gendered identities'. Another, ambiguous, contribution is her emphasis on history, and historical research, as a political resource for the understanding and transformation of contemporary ideological configurations.

There is something of a conceptual split between the way history is used here. On the one hand, history's usefulness stems from the ways it continues to inform present-day ideologies; on the other, it is valuable precisely because it illuminates for us the fact of the variability of the meanings of white femininity and the different ways in which white women situated themselves in relation to race and racism. We are led through the former strand to an expectation that direct connexions can be made between the past and the present, and that there are some immediate direct conclusions to be drawn from the historical material. But at the same time this is in tension with the 'history as the principle of difference/variability' line of argument, in which the series of case studies stand simply as ends in themselves, intrinsically interesting but arbitrary in selection, lacking any explanatory force and serving as images rather than arguments or analyses.

Insofar as one can draw conclusions from the historical discussion, it would seem that relations, ideological and political, between 
white women and race/racism, were more diverse in the early nineteenth century than in the late nineteenth century, when feminists were more constrained by or complicit in the imperialist codification of racist ideology. Across all this are some crucial issues: Ware lucidly considers the ways in which the construction of white woman as guardian/centre of civilization under sexual threat by black men served to legitimate racist and imperialist action, how for many white feminists as for racists, the 'degraded' black women were seen as an index of the lowly level of civilization reached by black society, in need of salvation by white women. Also important, and well-covered, is the range of ways in which white women articulated themselves through slave metaphors.

Ware is thinnest when she is focusing on feminist-identified activism as such, as in her chapter on feminists in the Empire, and strongest when she focuses on women in antiracism and the gender implications of that involvement. The most interesting chapter is on the 1890s anti-lynching campaign, in which the analyses of and by nineteenth-century African-American antiracist campaigner Ida Wells contribute to a fascinating exploration of the complex and confused connexions of white female sexuality, racism and emergent socialism.

The ambiguous use of history in this book is linked to a political and theoretical ambiguity in Ware's approach, which has to do with how she views notions of cultural/ethnic 'difference', what her connexions between a 'macro' and 'micro' level of analysis are, and her notions of political organization. On the one hand, underlying the book's organization, and its stated politics, seems a strong scepticism of any totalizing politics or analysis based on the redemption of grand narratives of history, feminism or socialism, as being destructive of the specificity or the validity of individual case studies, and, by extension, of the historical/conceptual specificity of culture/ethnicity; on the other, equally suggested by the book's organization and argument, these specificities seem to serve as a key to these grand narratives, which, far from being abandoned, are constantly gestured towards.

The implications, for a future feminist politics, are complicated. One is, as has already been said, a much-needed weighting of responsibility on the side of white feminism, to foreground analysis of the racialized elements of femininity and to strengthen its connexions with black and white antiracism. However, this weighting risks inadvertently equating black women with the politics of antiracism alone rather as Ida Wells, the only black woman to feature strongly in the book, is associated with antiracism. The analyses and politics of black feminists of the nineteenth and twentieth centuries are not Ware's concern, and need not be, except that the asymmetry of the discussion not only risks giving white-dominated feminism a monopoly on feminism, it also overlooks the success of existing political alliances made by women across ethnicities, based on what are perceived as common interests - as found, for instance, in Women Against Fundamentalism.

At the same time, the very real political questions of cultural difference are raised, but then fudged, by arguments such as 'white and black women can unite not so much in favour of women being able to wear headscarves but against the combination of gender, class and race relations that forbids cultural differences and fears that the dominant culture will be 'swamped' by an Other one' - the solution being to sidestep the thorny issues of sexist fundamentalism in favour of a relativist antiracist politics of cultural diversity?

Critique of the ways in which 
white femininity is historically constructed and racialized in dominant ideologies seems at times in Ware to come close to an endorsement of the view of the insurmountability of racial and cultural difference, and the leaving of women enclosed in their cultural/ethnic specificity and 'difference', a difference implied to be as valuable as it is inevitable. But at the same time, she appears to suggest, the importance of this ideology critique is precisely to overcome these divisions.

Overall, this is an important and provocative contribution to antiracism.

\section{Laura Chrisman}

\section{The Sphinx in the City}

\section{Elizabeth Wilson}

Virago: London 1991, ISBN

$185381282 \mathrm{X} £ 9.99 \mathrm{Pbk}$

In her recent book, Elizabeth Wilson argues 'that we will never solve the problems of cities unless we like the urban-ness of urban life' (p. 158). She is deeply critical of the antiurban sentiment prevalent in British and American culture, and insists upon the liberating potential of city life for women. Although the lives of women in Western societies are necessarily bound up with urban culture, feminist work in urban studies has remained rather separate from other feminist concerns. Wilson's book goes some way to bridging this gap, and in this review I endorse her emphasis on the significance of the city for feminism and of feminist perspectives for urban studies. At the same time I sound a note of caution in response to her optimistic appraisal of the prospects for women in cities.

Wilson's book is concerned with both the gender imagery of the city (and especially with the related oppositions of city/country and masculine/feminine), and peoples' everyday experiences of urban living. On the former, she suggests that 'male and female "principles" war with each other at the very heart of city life. The city is "masculine" in its triumphal scale, its towers and vistas and arid industrial regions; it is "feminine" in its enclosing embrace, in its indeterminacy and labyr- inthine uncentredness. We might even go so far as to claim that urban life is actually based on this perpetual struggle between rigid, routinised order and pleasurable anarchy, the male-female dichotomy.' (pp. 7-8) Wilson bemoans the tendency for the 'masculinity' of the city to dominate contemporary conceptions of urbanism. She implies that even feminist research on urban life falls into this trap, and, by focusing too narrowly on issues of safety, welfare and protection' (p. 10), promotes a view of women as victims of urbanization. In recovering the feminine imagery of the city, Wilson seeks 'a new vision, a new ideal of life in the city - and a new, "feminine" voice in praise of cities' (p. 11). She points to the possibilities for 'alternative' living arrangements in cities, to the advantages of anonymity and to the spontaneity and freedom associated with the city.

While her historical account of the gender connotations of urbanism and urban form is certainly appealing, the book is weaker in its treatment of the practical realities of urban living. Two aspects of this merit consideration. First, the links between the gender inflections of our conceptions of the city and everyday urban life remain poorly specified. Secondly, Wilson underplays the deeply divided character of women's experience of the city. I elaborate each of these criticisms in turn.

Existing research on women and urban living, which Wilson so readily dismisses, actually illuminates some of the interconnexions between 